\title{
Ketajaman Mata Dalam Kriteria Visibilitas Hilal
}

\author{
Muhammad Faishol Amin \\ (Email: faisholamin2301@gmail.com)
}

\begin{abstract}
Abstrak
Dalam kriteria visibilitas hilal, ada beberapa faktor yang seharusnya menjadi variabel pendukung dalam perumusan kriteria, diantaranya adalah faktor konfigurasi benda langit (Astronomi), Geografi, Meteorologi dan kualitas instrumen, dalam hal ini kualitas instrumen dapat berupa teleskop dan juga organ mata sebagai subjek utama dalam rukyatul hilal, yang nantinya akan berhubungan dengan faktor akuitas mata (ketajaman mata). Berdasarkan praktek dilapangan, kriteria visibilitas hilal ini tidak pernah menerapkan faktor ketajaman mata sebagai acuan perumusannya, namun Judhistira Aria Utama bersama Binta Yunita sempat meneliti tentang hal tersebut, ia mengkaji faktor ketajaman mata dan penerapannya dalam kriteria visibilitas hilal Kastner. Ia juga berusaha untuk memecahkan kasus pengamatan hilal rekor dunia yang menurut kriteria Kastner tidak mungkin dapat diamati, tetapi dalam prakteknya berhasil untuk diamati. Dari kajian tersebut disimpulkan bahwa : 1) Faktor ketajaman mata sangat berperan penting dalam berhasil tidaknya hilal terlihat saat pengamatan, hal tersebut dikarenakan kemampuan mata tiap individu yang berbeda-beda, ada yang normal, ada yang dibawah normal (cacat), bahkan ada yang mempunyai kemampuan mata diatas normal. 2) Dalam prakteknya faktor ketajaman mata belum pernah diterapkan, baik dalam kriteria visibilitas hilal, maupun dalam penetapan awal bulan Kamariah. 3) Ketajaman mata harus dipertimbangkan dalam rukyatul hilal, meskipun hal tersebut dirasa rumit jika diterapkan dalam sebuah kriteria, namun ada alternatif lain yang bisa dipakai yaitu menjadikan faktor ketajaman mata sebagai bahan pertimbangan atau bahan verifikasi terhadap laporan hasil rukyatul hilal. Jadi dalam penerimaan atau penolakan sebuah laporan rukyatul hilal harus ada faktor ketajaman mata dari pengamat yang berhasil melihat hilal, yang menjadi pertimbangan mungkin tidaknya hilal dilihat oleh orang tersebut.
\end{abstract}

\section{Kata Kunci : Rukyatul Hilal, Ketajaman Mata, Kriteria Visibilitas Hilal}

\section{A. Prolog}

Jauh sebelum munculnya kriteria MABIMS, sebenarnya sudah ada beberapa kriteria visibilitas hilal yang didasarkan pada perhitungan (hisab) dan pengamatan (rukyah), diantaranya adalah kriteria Odeh (2006), Sultan (2007) dan Kastner (1976). Secara umum kriteria-kriteria tersebut dirumuskan berdasarkan pada hasil pengamatan dan juga perhitungan konfigurasi benda langit (MatahariBulan-Bumi).

Dalam rukyatulhilal sendiri, ada beberapa faktor yang seharusnya menjadi variabel pendukung dalam perumusan kriteria visibilitas hilal, diantaranya adalah faktor konfigurasi benda langit (Astronomi), Geografi,
Meteorologi dan kualitas instrumen, dalam hal ini kualitas instrumen dapat berupa teleskop dan juga organ mata sebagai subjek utama dalam rukyatul hilal, yang nantinya akan berhubungan dengan faktor akuitas mata (ketajaman mata). Hoffman menyatakan bahwa prediksi kenampakan hilal ini melibatkan berbagai disiplin ilmu, tidak hanya astronomi saja, tetapi juga ilmu optika, meteorologi dan fisiologi. ${ }^{1}$

Ada sebuah penelitian yang dilakukan oleh Judhistira, terkait penerapan faktor-faktor pendukung

${ }^{1}$ Roy E. Hoffman, Observing The New Moon, Mon. Not. R. Astron Soc.340, 2003. hal. 1039. 
dalam kriteria visibilitas hilal. Dalam penelitian ini Judhistira memakai kriteria visibilitas Kastner sebagai acuan perumusannya. Perumusan tersebut menambahkan beberapa variabel, diantaranya seperti yang penulis sebut diatas, namun ada satu hal yang menarik bagi penulis, Judhistira menerapkan variabel akuitas mata sebagai klaim atas kasus-kasus yang tak terbantahkan (kasus hilal terlihat, tapi secara astronomi hilal tersebut tidak mungkin untuk dapat dilihat). Kasus-kasus atau pengamatan yang dijadikan dasar oleh Judhistira adalah pengamatan hilal yang dirangkum oleh Odeh dan Kasus pengamatan yang menjadi rekor dunia, diantaranya adalah rekor pengamatan hilal dengan mata telanjang oleh Ashdod pada tahun 1990 dengan lag time terpendek yaitu 29 menit. $^{2}$

Di Indonesia sendiri pun ada kasus-kasus yang tak terbantahkan seperti kasus/pengamatan diatas. Laporan hilal terlihat, namun dalam penerapannya laporan tersebut ditolak atas dasar kriteria visibilitas hilal MABIMS, contoh kasus terbaru terjadi pada penentuan awal bulan Muharam 1439 H/20 September 2017. Hilal dilaporkan terlihat di Pasuruan oleh Inwanuddin dan Shofiyyul Muhibbin, dalam hal ini pemerintah menerima laporan tersebut, tetapi Ormas Nahdhatul Ulama menolaknya dengan dasar kriteria MABIMS belum terpenuhi di lokasi tersebut. Pada saaat itu, di wilayah Indonesia sendiri, nilai tinggi hilal bervariasi antara $-0,25$ sampai 2,25 derajat, tetapi untuk ketinggian hilal di Pasuruan, berdasarkan hisab Nahdhatul Ulama, nilainya sebesar $1^{\circ} 55^{\prime}$, jadi memang

\footnotetext{
${ }^{2}$ Mohamad SH. Odeh, New Criterion for Lunar Crescent Visibility, Experimental Astronomy 18:39-64, hal. 62.
}

belum memenuhi kriteria visibilitas hilal MABIMS. ${ }^{3}$

Kriteria MABIMS sendiri dalam perumusannya berdasarkan pada kompilasi hasil pengamatan hilal internasional, jadi didalam kriteria MABIMS belum ada faktor Meteorologi dan akuitas mata yang dijadikan sebagai bahan pertimbangan. Kriteria MABIMS yang baru menghasilkan kriteria tinggi hilal minimal $3^{\circ}$, yang diambil dari penelitian Ilyas (1988), CaldwellLaney (2001) dan elongasi bulan $6,4^{\circ}$, diambil dari penelitian Odeh (2006). ${ }^{4}$ Kriteria tersebut merupakan revisi dari kriteria visibilitas hilal yang lama, yang sudah dianggap tidak lagi relevan untuk dijadikan sebagai acuan kriteria visibilitas hilal. Kriteria yang lama menerapkan faktor ketinggian hilal $2^{\circ}$, elongasi $3^{\circ}$, dan umur hilal 8 jam.

Faktor akuitas mata sendiri merupakan faktor yang sangat menentukan dalam rukyatul hilal, tingkat ketajaman mata tiap individu pasti berbeda-beda, dan untuk menentukan terlihat tidaknya hilal pasti bergantung pada tingkat ketajaman mata tiap individu tersebut. Seseorang yang mempunyai kekurangan atau cacat terhadap matanya, dengan tanpa alat bantu pasti akan sangat kesulitan dalam mencari cahaya hilal, mengingat cahaya hilal yang sangat tipis dan nilai kontrasnya yang sangat kecil. Bagi orang normal saja itu merupakan hal yang sangat sulit, apalagi bagi orang yang mempunyai kekurangan atau cacat mata.

Untuk mendefinisikan kemampuan mata, ada beberapa aspek

\footnotetext{
${ }^{3}$ LF PBNU, Surat Penjelasan LFPBNU tentangPenentuanAwalBulan Muharram1439 H. Nomor : 037/PBNU-LF/IX/2017 M. hal. 5 ${ }^{4}$ DrafKeputusanMuzakarahRukyahdan Takwim Islam Negara Anggota MABIMS ke16, 2-4 Agustus 2016, KompleksBaitulHilal, Port Dickson, Negeri Sembilan.
} 
yang berperan penting dalam penglihatan, diantaranya yaitu ketajaman pandangan dan sensitivitas kontras.Faktor tersebut merupakan faktor-faktor yang dipandang berpengaruh dalam ilmu fisika optik, dan penerapannya dalam ilmu astronomi, belum ada pembahasan lebih lanjut mengenai hal tersebut.

Dari beberapa pemaparan diatas, penulis tertarik untuk mengkaji faktor akuitas mata tersebut dan ingin mengkaitkannya dengan penerapan kriteria visibilitas hilal. maka dalam penelitian kali ini akan dibahas mengenai 1) Apa saja faktor yang mempengaruhi ketajaman mata? 2) Apa saja faktor yang harus diperhitungkan dalam perumusan kriteria visibilitas hilal? dan 3) seberapa besar urgensi penerapan ketajaman mata dalam kriteria visibilitas hilal?.

\section{B. Faktor-faktor Mempengaruhi Mata}

Sebagai alat penginderaan manusia, mata memiliki beberapa kemampuan dari segi visual, sehingga mata dapat menerima informasi dari lingkungan dengan cara melihat. Beberapa kemampuan mata adalah sebagai berikut:

\section{1) Akomodasi}

Akomodasi adalah suatu proses pemfokusan dan penyesuaian lingkungan lensa mata, yang dilakukan dengan menggunakan otot getar di sekitar lensa mata. ${ }^{5}$ Kemampuan ini digunakan untuk menyesuaikan diri terhadap objek yang dilihatnya. Secara fisis proses akomodasi ini dapat dilihat dari keadaan menebal atau menipisnya lensa mata.

Lebih mudahnya, dalam pengambilan gambar oleh kamera

\begin{tabular}{lr}
\hline${ }^{5}$ Eko. $\quad$ Nurmianto. & Ergonomi: \\
KonsepDasardanAplikasinya. & Surabaya: \\
GunaWidya, 1996. hal.217. &
\end{tabular}

DSLR, sering kita menjumpai hasil foto yang mempunyai titik fokus hanya pada satu objek, dan objek yang lain disekitarnya menjadi blur atau samar terlihat. Proses untuk mencari fokus itulah yang dimaksud dengan daya akomodasi.

Saat rukyatul hilal, salah satu proses penting yang perlu dilakukan oleh mata adalah fokus pada titik dimana hilal berada, tentunya mata yang mempunyai fungsi akomodasi yang kurang, akan kesulitan untuk mendapatkan fokus hilal tersebut.

2) Ketajaman pandangan ${ }^{6}$

Ketajaman pandangan adalah kemampuan mata untuk membedakan secara cermat (objek dan latarbelakangnya), yang sangat bergantung pada kemampuan akomodasi mata.

Ketajaman pandangan terdiri atas perbedaan persepsi atau jarak. Pada umumnya ketajaman pandangan bertepatan dengan kekuatan memecahkan suatu visual yang dihadapi oleh sistem optik. Untuk akomodasi mata lebih umum daripada ketajaman pandangan, akomodasi mata lebih kepada cepat lambatnya atau prosesyang dilakukan mata untuk memperoleh fokus suatu objek, sementara ketajaman mata lebih kepada rentang fokus yang dapat diproses oleh mata.

Ketajaman pandangan ini yang biasanya digunakan untuk menentukan penggunaan kacamata, dalam dunia klinik lebih dikenal dengan istilah visus. Tapi bagi seorang ahli fisika ketajaman pandangan ini biasanya disebut resolusi mata.

3) Kepekaan terhadap kontras (Contras Censitivity) $^{7}$

6 J.F. Gabriel, FisikaKedokteran. Jakarta :PenerbitBukuKedokteran EGC, 1996, hal. 154-155. 
Kontras merupakan tingkatan terang gelapnya suatu objek dibandingkan dengan latarnya. Ambang batas kontras adalah jumlah kontras minimal yang dibutuhkan untuk membedakan objek dengan latarnya. Sensitivitas kontras merupakan kebalikan dari ambang batas kontras yaitu kemampuan mata untuk mendeteksi perubahan cahaya yang minimal dalam mendeteksi suatu objek dengan berbagai frekuensi spasial dan atau berbagai tingkat kontras.

Ukuran suatu objek pun akan mempengaruhi berapa banyak kontras yang dibutuhkan untuk membedakan objek tersebut terhadap latarnya. Jika pembahasan ini ditarik dalam praktek rukyatul hilal, maka jumlah kontras hilal yang minimum terhadap latar belakang senja, akan bisa dilihat oleh orang yang mempunyai tingkat sensitivitas kontras yang baik (tinggi).

\section{4) Adaptasi}

Adaptasi adalah kemampuan mata untuk dapat menyesuaikan diri pada kondisi pencahayaan sumber informasi. Kemampuan ini disebabkan oleh fungsi sel-sel fotoreseptor yang ada pada retina, yaitu sel-sel antena dan sel-sel kerucut. Sel antena berfungsi pada kondisi pencahayaan rendah. Sedangkan sel kerucut berfungsi pada kondisi pencahayaan tinggi.

Pada tingkat perubahan cahaya yang mendadak, daerah pupil pada matalah yang pertama kali berubah sekitar 0,25. Daerah tersebut dapat berubah dengan suatu faktor sebesar $1: 16$. Proses yang terjadi kemudian kira-kira berlangsung dari 20 sampai 30 menit dari cahaya terang sampai

\footnotetext{
Ludwig MelinoTjokrovonco, PerananSensitivitasKontrasdalamFungsiPengl ihatan, DepartemenIlmuKesehatan Mata, FakultasKedokteranUniversiatasPadjadjaran. 2017. hal. 2-3.
}

kondisi gelap (adaptasi gelap). Adaptasi dari gelap ke terang biasanya berlangsung tidak lebih dari 3-2 menit (adaptasi terang).

Pengaruh dari terangnya suatu objek tergantung pada keadaan penerima dari mata. Jika daerah penglihatan mengandung suatu cahaya yang sangat terang, mata akan cenderung untuk menerimanya dan mengurangi kepekaannya sampai kewilayah yang lebih gelap. Penerangan dari suatu objek tergantung dari suasana terang yang ada disekelilingnya, dimana mata dapat menerima suasana tersebut.

Dalam pengamatan bintang saat malam hari contohnya, jangan mengharapkan angkasa langsung bersinar terang, berikanlah waktu secukupnya agar mata dapat menyesuaikan diri dalam kegelapan. Hal ini kemudian yang dikenal dengan istilah adaptasi mata, hal ini terjadi karena adanya perubahan fisis pada mata. Saat di kegelapan, pupil mata mula-mula akan membuka sebesar mungkin hingga sekitar $6,35 \mathrm{~mm}$. selanjutnya cairan yang disebut visual purple mengalir ke retina dan membuatnya lebih sensitif dari pada di siang hari. ${ }^{8}$

\section{Faktor-faktor Perumusan Kriteria Visibilitas Hilal}

Sebelum menentukan nilai kriteria visibilitas hilal, para astronom pastinya telah melakukan beberapa observasi hilal, yang selanjutnya hasil dari observasi hilal tersebut diambil kesimpulan bagaimana kondisi hilal yang bisa dilihat. Biasanya para astronom memakai beberapa parameter untuk menyatakan hilal mungkin dilihat atau tidak, namun mereka berbeda-beda dalam memakai parameter.

\begin{tabular}{cr}
\hline \multicolumn{1}{c}{ Robbin } & Kerrod, \\
BengkelImuAstronomi, & Jakarta \\
:PenerbitErlangga, 2005, hal.10. &
\end{tabular}


Ada beberapa variabel yang biasanya digunakan sebagai parameter dalam observasi, yang kemudian dipakai sebagai acuan penentuan kriteria visibilitas hilal :

1) Umur Bulan (Age)

Umur Bulan adalah Interval Waktu antara konjungsi/ijtimak dan Waktu observasi

2) Waktu Lag Bulan (Lag)

$$
\text { Waktu Lag adalah }
$$
Interval Waktu antara Matahari terbit dan Bulan terbit atau Matahari terbenam dan Bulan terbenam

3) Ketinggian Hilal (Altitude)

Ketinggian Hilal adalah Jarak yang dihitung dari Bulan yang tegak lurus dengan horizon

4) Elongasi ( $A R C L)$

Elongasi adalah Jarak antara Matahari dan Bulan

5) Beda Tinggi ( $A R C V$ )

Beda Tinggi adalah Jarak antara Matahari dan Bulan dalam ketinggian / beda tinggi Bulan dan Matahari

6) Beda Azimut (DAZ)

Beda Azimut adalah Jarak antara Matahari dan Bulan dalam azimut/ beda azimut antara Matahari dan Bulan

7) Lebar Hilal $(W)$

Lebar Hilal adalah Lebar dari cahaya hilal yang diukur dari diameter Bulan

Dari beberapa parameter di atas, 3 yang sering dipakai adalah elongasi (ARCL), Beda Tinggi $(A R C V)$, dan Beda Azimut (DAZ).

${ }^{9}$ Mohamad SH. Odeh, New Criterion for Lunar Crescent Visibility, opcit., hal. 41

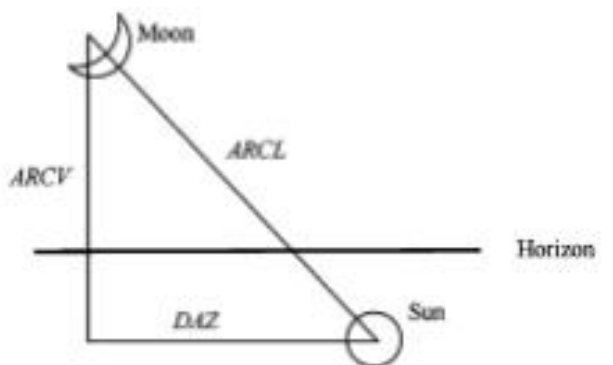

Gambar 1. Parameter ARCL, ARCV dan

$$
D A Z^{10}
$$

a) Kriteria Visibilitas Hilal Odeh Menurut Odeh, visibilitas hilal tidak bisa diprediksi hanya dengan satu parameter saja, meskipun ada satu kriteria yang hanya memakai satu parameter saja, yakni kriteria yang diusung oleh Schaefer (kriteria hanya berdasarkan umur atau lag time), namun kriteria tersebut tidak bisa langsung dipakai dan harus diolah terlebih dahulu.

Untuk menghasilkan kriteria visibilitas yang akurat harus memakai dua parameter, satu parameter berfungsi untuk menyatakan kecerahan hilal, dan satu parameter lainnya untuk menyatakan jarak hilal dengan ufuk. ${ }^{11}$

Asumsi yang paling sering digunakan oleh para ilmuwan astronomi untuk menyatakan cahaya hilal adalah elongasi ( $A R C L)$, karena cahaya hilal akan semakin bertambah seiring dengan bertambah besarnya elongasi Bulan dari Matahari, namun jika memakai faktor elongasi ini, masih ada celah kekurangan yang akan terjadi, yaitu elongasi akan menghasilkan kriteria dari cahaya hilal yang sama dalam posisi perigee maupun apogee. Maka dari itu menurut Odeh, kriteria yang paling tepat untuk mendefinisikan cahaya hilal adalah lebar hilal $(W)$, yang kemudian digandengkan dengan
${ }^{10}$ ibid.
${ }^{11}$ ibid. 
parameter kedua yaitu beda tinggi $(A R C V){ }^{12}$

Nilai $W$ sendiri dapat diketahui dari nilai $A R C L, A R C V$ dan $D A Z$, dengan rumus :

$$
\begin{gathered}
W=15(1-\cos A R C L)-15 \\
(1-\cos A R C V \cos D A Z)^{13}
\end{gathered}
$$

Kriteria yang diusung oleh Odeh ini berdasar pada kombinasi 737 observasi yang pernah dilakukan oleh para observer, yakni : ${ }^{14}$

a) 294 obervasi yang berhasil dilakukan oleh Scaefer

b) 6 obervasi yang berhasil dilakukan oleh Jim Stamm

c) 42 obervasi yang berhasil dilakukan oleh SAAO

d) 15 obervasi yang berhasil dilakukan oleh Mohsen Mirsaeed

e) 57 obervasi yang berhasil dilakukan oleh Alireza Mehrani

f) 323 obervasi yang berhasil dilakukan oleh ICOP

Observasi di atas diolah oleh Odeh menjadi hasil observasi yang memiliki 2 parameter, yaitu parameter beda tinggi (ARCV) dan parameter lebar hilal $(W)$. Kalkulasi kriteria ini telah dicantumkan oleh Odeh dalam programnya Accurate Times. Kriteria yang diusung oleh Odeh digambarkan dalam tabel berikut :

\footnotetext{
12 ibid.hal. 41-42
}

13 B.D. Yallop ,A Method for Predicting the First Sighting of the New Crescent Moon, NAO Technical Note No.69, hal. 2.

${ }^{14}$ Mohamad SH. Odeh, New Criterion for Lunar Crescent Visibility.opcit.hal. 43

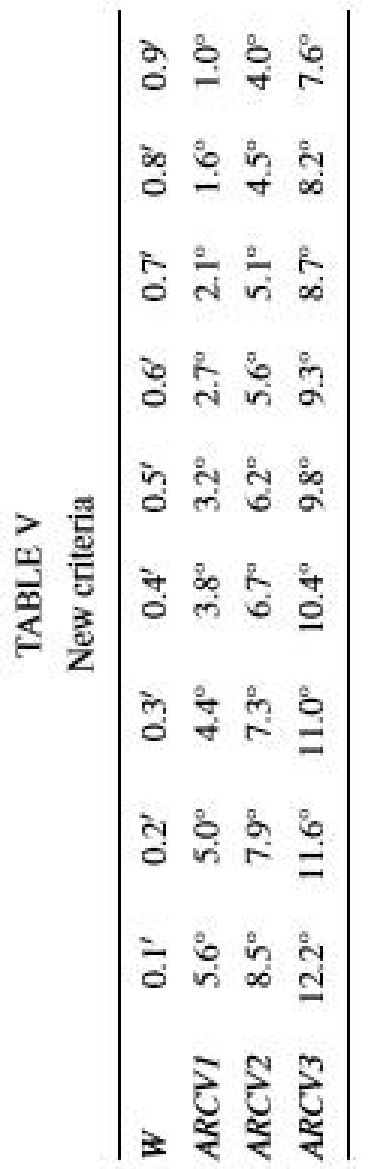

Tabel 1. Kriteria Visibilitas Hilal Mohammad Syawkat Audah

Tabel tersebut digunakan dengan keterangan sebagai berikut :

- Zona A

Visibilitas hilal mata telanjang, hilal dapat dilihat dengan semua sarana baik dengan mata telanjang, maupun dengan alat optik, yaitu jika $A R C V \geq$ ARCV3

- Zona B

Visibilitas hilal alat optik dan mungkin dengan mata telanjang, yaitu jika $A R C V \geq A R C V 2$

- Zona C

Visibilitas hilal dengan alat optik saja, dan tidak mungkin dengan mata telanjang, yaitu jika $A R C V \geq A R C V 1$

- Zona D

Hilal tidak bisa dilihat dengan semua sarana baik mata telanjang 
maupun alat optik, yaitu jika $A R C V<A R C V 1^{15}$

Kriteria di atas dapat dipahami, misalnya jika nilai lebar hilal $(W)=$ $0,4^{\prime}$ dan nilai $A R C V=6,8^{\circ}$, maka hilal bisa dilihat dengan alat optik dan mungkin dilihat oleh mata telanjang, dan contoh lain jika nilai lebar hilal $(W)=0,3^{\prime}$ dan nilai $A R C V=5,5^{\circ}$, maka hilal tidak bisa dilihat dengan sarana apapun.

Kriteria di atas tersebut meniadakan kondisi atmosfer yang ada, jadi sebagai contoh apabila nilai $A R C V$ berada di bawah zona $\mathrm{C}$, dan kondisi atmosfer buruk,maka tidak tentu hilal bisa dilihat, meskipun dengan alat optik. $^{16}$

\section{b) Kriteria MABIMS ${ }^{17}$}

Kriteria MABIMS lama dengan parameter tinggi hilal $2^{\circ}$, elongasi $3^{\circ}$ atau umur bulan 8 jam secara astronomis dianggap terlalu rendah, walau ada beberapa kesaksian yang secara hukum dapat diterima karena saksi telah disumpah oleh Hakim Pengadilan Agama, namun, dengan kriteria 2-3-8 tersebut, sabit hilal masih terlalu tipis sehingga tidak mungkin mengalahkan cahaya syafak (cahaya senja) yang masih cukup kuat pada ketinggian 2 derajat setelah matahari terbenam. Oleh karenanya dalam beberapa pertemuan Tim Hisab Rukyat Kementerian Agama dan pertemuan anggota MABIMS (Brunei Darussalam, Indonesia, Malaysia, dan Singapura) kriteria 2-3-8 diusulkan untuk diubah.

\footnotetext{
${ }^{15}$ ibid.

${ }^{16}$ ibid.hal.61

17 Thomas Djamaluddin, Naskah

Akademik Usulan Kriteria Astronomis Penentuan Awal Bulan Hijriyah, padahttps://tdjamaluddin.wordpress.com/2016/ 04/19/naskah-akademik-usulan-kriteriaastronomis-penentuan-awal-bulanhijriyah/diaksestanggal 20 November 2017, pukul 11:56 WIB.
}

Kriteria imkan rukyat atau visibilitas hilal adalah kriteria yang diharapkan bisa mempertemukan metode rukyat dan hisab. Kriteria itu disusun berdasarkan data rukyat jangka panjang yang dianalisis dengan perhitungan astronomi (hisab). Dalam implementasinya, kriteria itu digunakan untuk menolak kesaksian rukyat yang meragukan, karena hilal yang sangat muda dan terlalu rendah bentuknya masih sangat tipis, tidak mungkin mengalahkan cahaya syafak di dekat ufuk yang masih cukup kuat setelah matahari terbenam. Kriteria itu juga digunakan oleh ahli hisab dalam menentukan awal bulan kamariah ketika membuat kalender.

Imkan rukyat atau visibilitas hilal secara umum ditentukan oleh ketebalan sabit bulan dan gangguan cahaya syafak. Hilal akan terlihat kalau sabit bulan (hilal) cukup tebal sehingga bisa mengalahkan cahaya syafak.

Ketebalan hilal bisa ditentukan dari parameter elongasi bulan (jarak sudut bulan-matahari). Kalau elongasinya terlalu kecil (bulan terlalu dekat dengan matahari), maka hilal sangat tipis. Sementara itu parameter cahaya syafak bisa ditentukan dari ketinggian. Bila terlalu rendah, cahaya syafak masih terlalu kuat sehingga bisa mengalahkan cahaya hilal yang sangat tipis tersebut. Maka, kriteria imkan rukyat (visibilitas hilal) dapat ditentukan oleh dua parameter: elongasi dan ketinggian bulan.

Dalam kriteria MABIMS yang baru menghasilkan kriteria tinggi hilal minimal $3^{\circ}$, yang ambil dari penelitian Ilyas, Caldwell- Laney dan elongasi Bulan $6,4^{\circ}$, diambil dari penelitian Odeh.

Dari hasil rukyat jangka
panjang selama ratusan tahun,
diketahui bahwa elongasi minimal agar
hilal cukup tebal untuk bisa dirukyat
adalah 6,4 derajat (diambil dari kriteria


Odeh $)^{18}$. Dan dari data rukyat global, diketahui bahwa tidak ada kesaksian hilal yang dipercaya secara astronomis yang beda tinggi Bulan-Matahari kurang dari 4 derajat atau tinggi bulan saat matahari terbenam tidak ada yang kurang dari 3 derajat. Ilyas ${ }^{19}$ memberikan kriteria visibilitas hilal dengan beda tinggi bulan-matahari minimum $4^{\circ}$ (tinggi bulan minimum $3^{\circ}$ ). Dari data SAAO, Caldwell dan Laney $^{20}$ membuat kriteria visibilitas hilal dengan memisahkan pengamatan dengan mata telanjang dan dengan alat bantu optik. Secara umum, syarat minimal beda tinggi Bulan-Matahari menurut mereka adalah $>4^{\circ}$ atau tinggi bulan $>3^{\circ}$.

c) Kriteria Sultan dan Kastner Visibilitas hilal dalam model Kastner lebih ditekankan pada faktor kontras latar belakang senja, yaitu :

1) Kecerahan latarbelakang langit saat senja, hal ini dipengaruhi oleh cahaya Mataharimeskipun Matahari sudah tenggelam.

2) Ekstinsi atmosfer,faktor ini berhubungan dengan masa udara di suatu tempat.

3) Luminasi langit malam, faktor ini berasal dari cahaya langit, cahaya bintang dan cahaya zodiak. ${ }^{21}$

\footnotetext{
${ }^{18}$ Mohamad SH. Odeh, New Criterion for Lunar Crescent Visibility.opcit.hal.62

${ }^{19}$ Ilyas, M. Limiting Altitude Separation in The New Moon's First Visibility Criterion. AstronAstrophys, Vol.206. Tahun 1988, hal. 134.

20 Caldwell, JAR and Laney, First Visibility of the Lunar crescent, MNASSA, Vol.58, Nos. 11\&12, Tahun 2001, hal.157.

21 Sidney O. Kastner, Calculation of The Twilight Visibility Function Of Near-Sun Object, The Journal Of The Royal Astonomical Society Of Canada Vol.70 No.4. Tahun 1976. hal. 154-159
}

Ketiga faktor tersebut dikalkulasi dan nilainya harus lebih kecil daripada nilai kecerahan hilal sehingga akan menghasilkan visibilitas hilal positif. ${ }^{22}$ Dalam perhitungan sebelumnya juga dibutuhkan beberapa faktor astronomis sebagai acuan perhitungan, diantaranya adalah jarak zenit, beda azimut, sudut depresi Matahari (sebaran cahaya Matahari), magnitude semu visual Bulan dan Semi Diameter. ${ }^{23}$

Sementara itu untuk kriteria visibilitas hilal Sultan, parameter yang digunakan oleh Sultan hampir sama dengan Kastner. Parameter menurut Sultan yaitu $:^{24}$

1) Geometri Matahari, Bulan dan Ufuk.

2) Lebar dan Iluminasi Hilal

3) Penyerapan Cahaya Bulan Oleh Atmosfer

4) Penyebaran Cahaya di Atmosfer.

5) Psikofisologi penglihatan manusia

Untuk 3 faktor pertama bisa dihitung secara mudah. Kalkulasi parameter ke-4 harus berdasarkan pada lokasi tertentu. Dan untuk faktor ke-5 tentang penglihatan manusia Sultan lebih mengarah kepada definisi sudut visual, seperti pendapat Blackwell yang dikutip olehClark tentang kemungkinan terlihatnya objek benda langit berdasarkan ambang batas kontras. Jika kontras antara permukaan objek dan background lebih besar daripada ambang batas kontras, maka objek dapat dilihat, dan jika kontras antara permukaan objek dan background lebih kecil daripada

\footnotetext{
${ }^{22}$ Ibid. hal. 160

23 Judhistira A. Utama, dkk. Criteria OfHilal Visibility in Indonesia by Using Kastner Model, JurnalPendidikanFisika Indonesia Vol.9 Tahun 2013. Hal. 200.

${ }^{24}$ A. H. Sultan, First Visibility of The Lunar Crescent : Beyond Danjon's Limit. The Observatory Journal Vol.127. Tahun 2007 hal.54.
} 
ambang batas kontras maka tidak bisa dilihat. ${ }^{25}$

\section{Urgensi Penerapan Ketajaman Mata dalam Kriteria Visibilitas Hilal}

Dari penjelasan mengenai beberapa kriteria visibilitas hilal diatas, belum ada satupun kriteria yang menerapkan faktor ketajaman (akuitas) mata dalam perumusannya, padahal faktor ini juga cukup penting untuk menentukan mungkin tidaknya hilal terlihat oleh seseorang.

Memang akan cukup rumit bila faktor akuitas mata ini diterapkan sebagai salah satu faktor dalam perumusan sebuah kriteria visibilitas hilal, karena mengingat perbedaan tingkat ketajaman mata tiap individu pasti berbeda-beda, namun jika kita mengingat adanya penolakan terhadap laporan terlihatnya hilal dan alasan penolakan tersebut hanya karena berlandaskan faktor astronomis tentunya itu dirasa kurang tepat, karena selain faktor meteorologi yang belum diperhitungkan, faktor akuitas mata pun belum menjadi koreksi dalam hasil rukyatul hilal tersebut, padahal faktor akuitas mata ini sangat berpengaruh dalam keberhasilan terlihatnya hilal.

Rukyatul hilal memang bukanlah suatu hal yang mudah, hanya beberapa persen saja dari keseluruhan para pegiat ilmu falak/observer yang pernah melihat hilal awal bulan kamariah secara langsung. Pernyataan tersebut penulis peroleh dari beberapa para pakar falak yang telah melakukan kegiatan rukyatul hilal setiap bulan, dalam puluhan tahun, namun jarang sekali, bahkan tidak pernah sekalipun melihat wujud hilal penentu awal bulan tersebut.

25 A. H. Sultan, Explaining and Calculating The Length Of The New Crescent Moon. The Observatory Journal Vol.125. Tahun 2005 hal.228-229.
Disamping itu, ada beberapa pengamatan hilal yang termasuk menarik untuk dikaji, karena pengamatan-pengamatan tersebut termasuk ke dalam rekor dunia. Pengamatan tersebut menjadi rekor dunia berdasarkan kriteria umur bulan/lagtime/elongasi terendah. Rekor inilah yang kemudian dijadikan salah satu faktor/variabel penentuan kriteria visibilitas hilal oleh M. Odeh. Berikut ini data rekor dunia untuk pengamatan hilal :

\begin{tabular}{|c|c|c|c|}
\hline $\begin{array}{l}\mathbf{N} \\
\mathbf{o}\end{array}$ & $\begin{array}{c}\text { Obser } \\
\text { ver }\end{array}$ & $\begin{array}{l}\text { Waktu } \\
\text { Pengamatan }\end{array}$ & Keterangan \\
\hline 1 & Pierce & $\begin{array}{l}25 / 02 / \\
1990\end{array}$ & $\begin{array}{l}\text { Mata Telanjang, } \\
\text { Umur Bulan } 15 \\
\text { Jam } 33 \text { Menit }\end{array}$ \\
\hline 2 & Stamm & $\begin{array}{l}20 / 01 / \\
1996\end{array}$ & $\begin{array}{l}\text { Teleskop, Umur } \\
\text { Bulan } 13 \text { Jam } 14 \\
\text { Menit }\end{array}$ \\
\hline 3 & Mirsaeed & $\begin{array}{l}07 / 09 / \\
2002\end{array}$ & $\begin{array}{l}\text { Binokuler, Umur } \\
\text { Bulan } 13 \text { Jam } 18 \\
\text { Menit }\end{array}$ \\
\hline 4 & Stamm & $\begin{array}{l}02 / 11 / \\
2005\end{array}$ & $\begin{array}{l}\text { Teleskop, Lag } \\
\text { Time } 21 \text { Menit }\end{array}$ \\
\hline 5 & Ashdod & $\begin{array}{l}20 / 09 / \\
1990\end{array}$ & $\begin{array}{l}\text { Mata Telanjang, } \\
\text { Lag Time } 29 \\
\text { Menit }\end{array}$ \\
\hline 6 & Stamm & $\begin{array}{l}13 / 10 / \\
2004\end{array}$ & $\begin{array}{l}\text { Teleskop, } \\
\text { Elongasi } 6,4^{\circ}\end{array}$ \\
\hline 7 & Pierce & $\begin{array}{l}25 / 02 / \\
1990\end{array}$ & $\begin{array}{l}\text { Mata Telanjang, } \\
\text { Elongasi } 7,7^{\circ} .\end{array}$ \\
\hline
\end{tabular}

Tabel 2. Data Rekor Dunia Pengamatan Hilal $^{26}$

Selain rekor dunia diatas, di Indonesia juga sebenarnya ada beberapa kasus yang menarik pula untuk dikaji, ada beberapa pengamatan hilal yang secara ilmiah (menurut kriteria MABIMS) hilal tidak mungkin terlihat, namun dalam kenyatannya ada laporan

${ }^{26}$ Mohamad SH. Odeh, New Criterion for Lunar Crescent Visibility.opcit.hal.62 
keberhasilan terlihatnya hilal. kasus terbaru terjadi pada penentuan awal Muharam 1439 H (20 September 2017) yang sempat membingungkan masyarakat yang awam akan dunia per-hilal-an.

Pada saat itu kondisi hilal di Indonesia memang terbagi menjadi 2 daerah, ada daerah yang memenuhi kriteria, dan ada yang dibawah kriteria.

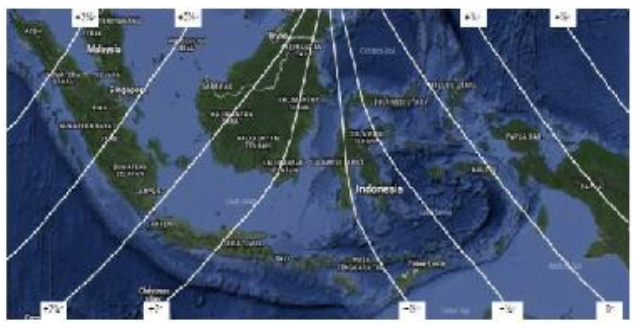

Gambar 2. Peta Hilal Mar'i Muharam 1439 berdasarkan hisab Nahdhatul Ulama ${ }^{27}$

Secara hisab, berarti ada kemungkinan hilal terlihat di daerah yang sudah memenuhi kriteria MABIMS, namun dalam prakteknya hilal tersebut malah berhasil terlihat di daerah yang belum memenuhi kriteria MABIMS, yakni di Pasuruan dengan ketinggian hilal menurut hisab NU bernilai $1^{\circ} \quad 55^{\prime}$. Sehingga dalam penetapan awal bulan Muharam 1439 ada perbedaan. Ada pihak yang memakai hisab dengan acuan markas di daerah yang sudah memenuhi kriteria visibilitas hilal, memulai 1 Muharam 1439 pada malam itu, dan ada pihak yang memulai 1 Muharam pada malam esoknya dan berdasar pada rukyatul hilal yang tidak berhasil dilakukan (berhasil tapi ditolak).

Ada banyak faktor yang mempengaruhi berhasil tidaknya praktek rukyatul hilal, dalam papernya,Hoffman menyatakan bahwa

\footnotetext{
27 LF PBNU, Surat Penjelasan LFPBNU tentangPenentuanAwalBulan Muharram1439 H.opcit. hal. 2
}

prediksi kenampakan hilal ini melibatkan berbagai disiplin ilmu, tidak hanya astronomi saja, tetapi juga ilmu optika, meteorologi dan fisiologi. ${ }^{28}$ Ilmu optika berkaitan dengan proses perambatan cahaya dari sumber di luar atmosfer hingga tiba di detektor di permukaan Bumi. Meteorologi berperan dalam menyediakan informasi dinamika atmosfer lokal yang direpresentasikan ke dalam parameter temperatur, kelembaban, dan tekanan udara serta kandungan aerosol yang berkenaan dengan kadar transparansi atmosfer setempat. Sementara itu Fisiologi berhubungan dengan bagaimana detektor, dalam hal ini mata manusia, merespon informasi berupa foton yang tiba dari sumber. ${ }^{29}$

Dari sini kita bisa mengetahui bahwa dalam memperkirakan terlihat atau tidaknya hilal, membutuhkan faktor-faktor yang sangat kompleks, diantaranya yang telah disebut diatas adalah faktor fisiologi yang berbicara mengenai detektor atau mata manusia sebagai subjek pelaku dalam observasi/rukyatul hilal, baik itu nanti menggunakan alat bantu maupun tidak.

Jika kita kembali lagi pada data pengamatan rekor dunia, ternyata tidak semua kriteria visibilitas hilal sama hasilnya dengan pengamatan tersebut. Ada kriteria yang menganggap bahwa beberapa hilal yang termasuk dalam rekor dunia tersebut tidak mungkin untuk dapat diamati. Diantaranya adalah kriteria visbilitas hilal Kastner dan Sultan. Berdasar pada kriteria Kastner Hilal pada kasus pengamatan No.5 (Tabel 2) masih mempunyai nilai

\footnotetext{
${ }^{28}$ Roy E. Hoffman, Observing The New Moon, opcit.hal. 1039.

${ }^{29}$ Judhistira, A.U. danHilmansyah, Penentuan Parameter FisisHilalsebagaiUsulanKriteriaVisibilitas di Wilayah Tropis. JurnalFisika Vol. 3 No.2, Nopember 2013. Hal. 122.
} 
visibilitas hilal yang negatif $(-1,94)$ sehingga tidak mungkin untuk dapat diamati, karena nilai kontras latar belakang senja masih terlalu cerah bila dibandingkan dengan iluminasi hilal pada saat itu.

Binta bersama Judhistira merumuskan modifikasi untuk model kriteria Kastner, sehingga visibilitas hilal dalam kriteria Kastner mempunyai nilai positif pada pengamatan No.5 tersebut. Judhistira menerapkan faktor yang jarang sekali disentuh oleh ahli astronomi untuk penentuan kriteria visibilitas hilal, yaitu faktor fisiologi atau ketajaman(akuitas) mata. Faktor akuitas tersebut diterapkan karena terdapat kasus dimana beberapa pengamat memiliki kemampuan penglihatan di atas rata-rata. ${ }^{30}$ Menurut Schaefer, tingkat akuitas mata setiap individu berbeda-beda, untuk pengamat dengan penglihatan normal, besaran akuitas mata bernilai $\mathrm{F}_{\mathrm{s}}=1$, dan untuk pengamat dengan penglihatan paling baik bernilai $\mathrm{Fs}=$ $\begin{array}{lllll}0,1 & - & 0,2 . & 31 & \text { Dalam }\end{array}$ penelitianJudistiradilakukan analisis besaran faktor akuitas mata $\left(\mathrm{F}_{\mathrm{s}}=0,15\right)$ pada model Katsner untuk peningkatan akurasi prediksi model Katsner yang sudah dimodifikasi. ${ }^{32}$

Hal tersebut pulalah yang seharusnya perlu dilakukan oleh para ahli falak di Indonesia. Seluruh laporan pengamatan hilal di Indonesia

30 Binta, YunitadanJudhistira, Model VisibilitasKastnerdalamKasusHilalRekorDuni adenganMenyertakanFaktorAkuitas Mata Pengamat. Prosiding Seminar Nasional SainsAntariksa (SNSA), LAPAN. 2016. Hal 60.

31 Bradley E. Schaefer, Telescopic Limitng Magnitudes, Publications of The Astronomical Society of ThePasific, February 1990. Hal. 215. Lihat pula Binta, YunitadanJudhistira, Model... hal. 60.

${ }^{32}$ Binta, YunitadanJudhistira, VisibilitasKastnerdalamKasusHilalRekorDuni adenganMenyertakanFaktorAkuitas Mata Pengamat. opcit.hal. 59. setidaknya harus tetap dipertimbangkan dalam setiap pengamatan (meskipun diluar nalar), bukannyaditolak secara mentahmentah. Suhardiman berpendapat bahwa seharusnya keberhasilan pengamatan hilal di Indonesia yang bisa dikatakan diluar nalar astronomi, harus dijadikan bahan rujukan juga oleh para peneliti dan para ahli falak, karena sifat kriteria visibilitas hilal yang relatif dan tentatif. ${ }^{33}$

Dalam kasus laporan pengamatan hilal diluar nalar astronomi yang berhasil terlihat, bisa jadi ada faktor yang memang belum diperhitungkan dalam kriteria tersebut. Dan salah satu faktor yang belum pernah ada dalam perumusan kriteria visibilitas hilal adalah faktor ketajaman mata. Hal tersebut tidak bisa dipungkiri, bahwasanya memang faktor ketajaman mata ini sangat penting dalam sebuah pengamatan (rukyatul hilal), dan tetap harus dipertimbangkan, meskipun mustahil jika kita berusaha untuk merumuskannya kedalam sebuah kriteria visibilitas hilal.

Setiap individu pasti mempunyai tingkat ketajaman mata yang berbeda-beda, jika nanti faktor ketajaman mata dipaksakan akan diterapkan dalam sebuah kriteria visibilitas hilal maka seseorang dengan tingkat ketajaman mata tertentu pasti mempunyai kriteria visibilitas hilal tertentu, sehingga akan ada banyak kriteria untuk beberapa tingkat ketajaman mata yang berbeda. Sederhananya, orang dengan mata normal mempunyai kriteria sendiri danorang dengan kemampuan mata diatas rata-rata mempunyai kriteria sendiri dan seterusnya, dan hal tersebut tidak mungkin untuk dilakukan karena

\begin{tabular}{lr}
\hline \multicolumn{2}{c}{ Suhardiman, } \\
KriteriaVisibilitasHilaldalamPenetapanAwalB \\
ulan Kamariah di $\quad$ Indonesia. \\
JurnalKhatulistiwa. Vol. 3. No.1. hal.15.
\end{tabular}


meskipun kriteria visibilitas hilal bersifat relatif tentatif, tetapi kriteria visibilitas hilal pun tetap harus bersifat universal dalam suatu daerah yang menerapkan konsep wilayatul hukmi, agar dapat pula dipakai sebagai kriteria yang melandasi penyusunan kalender Kamariah.

Salah satu jalan keluar permasalahan tersebut adalah : Pertama, menyusun konsep tentang ketajaman mata secara rinci. Kedua, konsep tersebut tidak diterapkan ke dalam sebuah kriteria visibilitas hilal, namun konsep tersebut dapat dijadikan sebagai bahan pertimbangan atau bahan verifikasi terhadap laporan hasil rukyatul hilal. Jadi dalam menerima atau menolak sebuah laporan rukyatul hilal harus ada faktor akuitas mata dari pengamat yang berhasil melihat hilal, yang menjadi pertimbangan mungkin tidaknya hilal dilihat oleh orang tersebut.

\section{E. Penutup}

Dari beberapa pembahasan yang telah dipaparkan oleh penulis, dapat ditarik kesimpulan sebagai berikut :

1. Faktor ketajaman mata sangat berperan penting dalam berhasil tidaknya hilal terlihat saat pengamatan, hal tersebut dikarenakan kemampuan mata tiap individu yang berbeda-beda, ada yang normal, ada yang dibawah normal (cacat), bahkan ada yang mempunyai kemampuan mata diatas normal.

2. Dalam prakteknya faktor ketajaman mata belum pernah diterapkan, baik dalam kriteria visibilitas hilal, maupun dalam penetapan awal bulan Kamariah.

3. Ketajaman mata harus dipertimbangkan dalam rukyatul hilal, meskipun hal tersebut dirasa rumit jika diterapkan dalam sebuah kriteria, namun ada alternatif lain yang bisa dipakai yaitu menjadikan faktor ketajaman mata sebagai bahan pertimbangan atau bahan verifikasi terhadap laporan hasil rukyatul hilal. Jadi dalam penerimaan atau penolakan sebuah laporan rukyatul hilal harus ada faktor ketajaman mata dari pengamat yang berhasil melihat hilal, yang menjadi pertimbangan mungkin tidaknya hilal dilihat oleh orang tersebut.

\section{Daftar Pustaka}

Binta, Yunita dan Judhistira, Model Visibilitas Kastner dalam Kasus Hilal Rekor Dunia dengan Menyertakan Faktor Akuitas Mata Pengamat. Prosiding Seminar Nasional Sains Antariksa (SNSA), LAPAN. 2016.

Caldwell, JAR and Laney, First Visibility of the Lunar crescent, MNASSA, Vol.58, Nos. 11\&12, Tahun 2001.

Djamaluddin, Thomas. Naskah Akademik Usulan Kriteria AstronomisPenentuan Awal Bulan Hijriyah, pada https://tdjamaluddin.wordpress.c om/2016/04/19/naskah-

akademik-usulan-kriteriaastronomis-penentuan-awalbulan-hijriyah/ diakses pada 20 November 2017, pukul 11:56 WIB.

Draf Keputusan Muzakarah Rukyah dan Takwim Islam Negara Anggota MABIMS ke-16, 2-4 
Agustus 2016, Kompleks Baitul Hilal, Port Dickson, Negeri Sembilan.

Gabriel, J.F. Fisika Kedokteran. Jakarta : Penerbit Buku Kedokteran EGC, 1996.

Hoffman, Roy E. Observing The New Moon, Mon. Not. R. Astron Soc.340, 2003.

Ilyas, M. Limiting Altitude Separation in The New Moon's First Visibility Criterion. Astron Astrophys, Vol.206. Tahun 1988.

Kastner, Sidney O. Calculation of The Twilight Visibility Function Of Near-Sun Object, The Journal Of The Royal Astonomical Society Of Canada Vol.70 No.4. Tahun 1976.

Kerrod, Robbin. Bengkel Ilmu Astronomi, Jakarta : Penerbit Erlangga, 2005..

LF PBNU, Surat Penjelasan LFPBNU tentang Penentuan Awal Bulan Muharram1439 H. Nomor : 037/PBNU-LF/IX/2017 M.

Nurmianto, Eko. Ergonomi: Konsep Dasar dan Aplikasinya. Surabaya: Guna Widya, 1996.

Odeh, Mohamad SH. New Criterion for Lunar Crescent Visibility, Experimental Astronomy 18:3964.

Schaefer, Bradley E. Telescopic Limitng
Magnitudes,
Publications of The Astronomical Society of The Pasific, February 1990.

Suhardiman, Kriteria Visibilitas Hilal dalam Penetapan Awal Bulan Kamariah di Indonesia. Jurnal Khatulistiwa. Vol. 3. No.1.

Sultan, A. H. Explaining and Calculating The Length of The New Crescent Moon. The Observatory Journal Vol.125. Tahun 2005. .First Visibility of The Lunar Crescent : Beyond Danjon's Limit. The Observatory Journal Vol.127. Tahun 2007.

Tjokrovonco, Ludwig Melino. Peranan Sensitivitas Kontras dalam Fungsi Penglihatan, Departemen Ilmu Kesehatan Mata, Fakultas Kedokteran Universiatas Padjadjaran. 2017.

Utama, Judhistira A. dkk. Criteria Of Hilal Visibility in Indonesia by Using Kastner Model, Jurnal Pendidikan Fisika Indonesia Vol.9 Tahun 2013. , Penentuan Parameter Fisis Hilal sebagai Usulan Kriteria Visibilitas di Wilayah Tropis. Jurnal Fisika Vol. 3 No.2, Nopember 2013.

Yallop, B.D. A Method for Predicting the First Sighting of the New Crescent Moon, NAO Technical Note No.69. 